\title{
PERSEPSI DOSEN TERHADAP KRITERIA, REALITAS, DAN HARAPAN DALAM PELAKSANAAN SELEKSI CALON PIMPINAN STRUKTURAL PERGURUAN TINGGI NEGERI
}

\author{
H. M. Huda A. Y. \\ Universitas Negeri Malang, Jl. Semarang 5 Malang \\ email:muh_huda47@yahoo.com
}

\begin{abstract}
Perception Lecturer against Criteria, Reality and Expectation in the Implementation Selection of Structural Leaders Candidate. Universities and colleges in order to achieve the purpose, requires human resources, institutions, and the quality of leadership that is able to realize the goal. If the faculty of perception is positive, it will affect the creation of a climate conducive working environment, productive, effective, and efficient. The purpose of this study was to: (1) determine the criteria lecturer perception, reality and expectation in the implementation of the leader selection process, which consists of the rector and vice-rector; (2) investigate the implementation of leader selection of faculty in State University of Malang (UM). This study was designed in correlation with a quantitative approach with a qualitative and strengthened. The data collection is done by using a questionnaire. The results showed perceptions of professors against the criteria, reality, and expectations in the implementation of leader selection in State University of Malang (UM) environment is appropriate.
\end{abstract}

Keywords: perception, criteria, reality, expectation

\begin{abstract}
Abstrak: Persepsi Dosen terhadap Kriteria, Realitas, dan Harapan dalam Pelaksanaan Seleksi Calon Pimpinan Struktural. Perguruan tinggi dalam rangka mencapai tujuan, memerlukan sumber daya manusia, lembaga, dan kualitas pimpinan yang mampu mewujudkan tujuan. Apabila persepsi dosen positif, maka akan berdampak terciptanya iklim lingkungan kerja yang kondusif, produktif, efektif, dan efisien. Tujuan dari penelitian ini untuk: (1) mengetahui persepsi dosen terhadap kriteria, realita dan harapan dalam pelaksanaan seleksi calon pimpinan, yang terdiri dari rektor dan wakil rektor; (2) mengetahui pelaksanaan seleksi calon pimpinan fakultas di lingkungan Universitas Negeri Malang (UM). Penelitian ini dirancang secara korelasional dengan pendekatan kuantitatif dan diperkuat dengan kualitatif. Pengumpulan data dilakukan dengan menggunakan kuesioner. Hasil penelitian menunjukkan persepsi dosen terhadap kriteria, realita, dan harapan dalam pelaksanaan seleksi calon pimpinan di lingkungan UM sudah sesuai.
\end{abstract}

Kata kunci: persepsi, kriteria, realitas, harapan

Faktor yang menentukan pengembangan visi, misi, dan tujuan menyelenggarakan pendidikan tinggi adalah kualitas sumber daya manusia, terutama pimpinan dalam menyelenggarakan kepemimpinannya. Hakikat kepemimpinan terbagi menurut sifat individu, pengaruh individu, pengaruh individu terhadap orang lain, pola-pola interaksi, kedudukan administratif, dan persepsi orang lain mengenai legitimasi pengaruh (Yukl, 1991). Pengaruh kepemimpinan terhadap yang dipimpin mencakup ide, perasaan, sikap, dan perilaku. Kualitas seorang pemimpin dalam menyelenggarakan kepemimpinannya dapat dilihat dari keberhasilan pemimpin itu dalam memasyarakatkan gagasan, perasaan, sikap, dan perilaku terhadap yang dipimpin. 
Usaha mempengaruhi aspek kognisi, afeksi dan psikomotorik orang yang dipimpin, bukan tugas yang ringan dari setiap pemimpin. Oleh karena itu, keberhasilan pemimpin menjalankan pengaruh terhadap orang lain memerlukan personal characteristics. Unsur yang sangat penting dalam mengembangkan institusi di perguruan tinggi adalah pengaruh dosen. Kemampuan profesional dosen dalam hubungan yang tepat dengan mahasiswa dan sejawat, sangat menentukan perkembangan institusi, karena dosen dapat mempengaruhi lingkungan intelektual dan sosial kehidupan kampus (Sonhadji, 1990).

Proses seleksi dalam perspektif ilmu manajemen merupakan proses untuk menemukan pimpinan yang baik di antara sumber daya manusia yang ada. Proses seleksi bertujuan memilah dan memilih sumber daya manusia yang potensial untuk menempati posisi pimpinan sesuai dengan karekteristik lembaga yang dipimpin. Oleh karena itu, wajar jika setiap lembaga menyelenggarakan seleksi yang berbeda-beda sesuai dengan karakteristiknya. Universitas Negeri Malang (UM) dalam hal ini melaksanakan seleksi berlandaskan aturan yang ada pada Tri Dharma Perguruan Tinggi.

\section{METODE}

Penelitian ini dirancang secara korelasional dengan pendekatan kuantitatif dan diperkuat dengan kualitatif. Populasi dan sampel dalam penelitian ini adalah dosen UM yang sedang dan yang pernah menjabat pimpinan struktural tingkat universitas maupun fakultas, serta dosen yang sedang dan yang pernah menjadi anggota senat, baik tingkat universitas maupun tingkat fakultas. Penentuan sampel dilakukan dengan menggunakan teknik sampling purposive. Berdasarkan jumlah populasi sebanyak 187 orang dosen, diperoleh sampel sebanyak 96 orang dosen.

Pengumpulan data dilakukan dengan menggunakan kuesioner, yakni untuk mengetahui persepsi mengenai kriteria dan realitas seleksi pimpinan struktural serta harapan dosen mengenai kriteria seleksi pimpinan di lingkungan UM. Instrumen kuesioner dibuat berdasarkan jabaran dari dua variabel prediktor dan satu variabel kriterium, yaitu: (1) persepsi dosen terhadap kriteria seleksi pimpinan struktural (X1); (2) persepsi dosen terhadap realita seleksi pimpinan struktural (X2); dan harapan dosen terhadap kriteria seleksi pimpinan struktural (Y). Untuk ketiga jenis variabel yang diteliti, masing-masing butir pertanyaan diberi bobot skor 1 sampai dengan 4. Untuk mengetahui validitas butir instrumen dihitung dengan menggunakan rumus Korelasi Product Moment Pearson. Teknik yang digunakan untuk mengukur reliabilitas instrumen dalam penelitian ini digunakan rumus Cronbach Alpha dari Guilfor dan Fruchter (1978).

Teknik analisis data dalam penelitian ini menggunakan dua teknik, yaitu analisis deskriptif kuantitatif dan analisis deskriptif kualitatif. Teknik analisis deskriptif kuantitatif yang digunakan adalah harga rerata. Teknik ini digunakan untuk menganalisis data, sehingga memperoleh simpulan untuk variabel persepsi mengenai kriteria dan realitas seleksi pimpinan struktural serta harapan dosen mengenai kriteria seleksi pimpinan struktural. Mengingat tujuan penelitian ini untuk memperoleh gambaran atau deskripsi sebaran frekuensi untuk masing-masing varibel dari keseluruhan variabel yang ada. Teknik analisis deskriptif kualitatif digunakan untuk mendeskripsikan saran penyempurnaan dari sistem seleksi calon pimpinan struktural. Teknik ini digunakan dengan memahami kecenderungan saran penyempurnaan yang dikemukakan oleh responden.

\section{HASIL DAN PEMBAHASAN}

\section{Hasil}

\section{Persepsi Dosen terhadap Seleksi Rektor}

Persepsi dosen terhadap seleksi Rektor UM berada pada kategori cukup sesuai dengan aturan yang berlaku. Sedang persepsi dosen terhadap realita seleksi berada pada kategori cukup sesuai dengan aturan yang berlaku. Tentang harapan dosen terhadap kriteria seleksi berada pada kategori sesuai dan harapan dosen terhadap realita seleksi berada pada kategori cukup sesuai. Temuan tersebut sangat sesuai dengan data yang lebih bersifat kualitatif, yaitu bahwa dalam hal aspek kemampuan akademik, kepribadian, pengalaman, keahlian yang relevan memperoleh penilaian sangat memadai.

Beberapa aspek yang masih perlu memperoleh perhatian secara serius adalah kesehatan, 
manajerial, keterbukaan, penghayatan politik, pengerahan, dan alokasi sumber daya serta kerja sama. Komentar secara umum yang banyak disampaikan para dosen adalah agar pejabat struktural memiliki keterbukaan berkenaan dengan pelaksanaan berbagai bidang kegiatan. Salah satu dari perwujudan dari keterbukaan tersebut dapat dilakukan lewat penyelenggaraan dialog, diskusi maupun seminar dengan melibatkan secara langsung pihak-pihak yang terkait dengan permasalahan yang dibahas.

\section{Persepsi Dosen terhadap Seleksi Wakil Rektor 1}

Persepsi dosen terhadap realita seleksi berada pada kategori sesuai dengan aturan yang berlaku. Tentang harapan dosen terhadap kriteria seleksi berada pada kategori sesuai dan harapan dosen terhadap realita seleksi berada pada kategori cukup sesuai. Temuan tersebut sangat sesuai dengan temuan data yang lebih bersifat kualitatif, bahwa dalam aspek akademik, integritas, keahlian yang relevan, pengalaman, pengerahan dan alokasi sumber daya, kesehatan, penjabaran program pengembangan, pengawasan program kerja, kejujuran, penelitian, pendidikan dan pengajaran, kerja ilmiah nonpenelitian, kepribadian, keharmonisan keluarga, dan ketaqwaan berada pada kategori cukup memadai.

\section{Persepsi Dosen terhadap Seleksi Wakil Rektor 2}

Persepsi dosen terhadap realita seleksi berada pada kategori cukup sesuai dengan aturan yang berlaku. Tentang harapan dosen terhadap kriteria seleksi berada pada kategori sesuai dan harapan dosen terhadap realita seleksi berada pada kategori cukup sesuai. Temuan tersebut sangat sesuai dengan temuan data yang lebih bersifat kualitatif, bahwa dalam beberapa aspek seperti kesehatan, pengabdian kepada masyarakat dan keharmonisan keluarga cukup memadai, tetapi beberapa aspek lain masih perlu memperoleh perhatian untuk disempurnakan. Beberapa aspek yang masih perlu memperoleh perhatian serius untuk disempurnakan tersebut adalah aspek akademik, keahlian yang relevan, manajerial, pengalaman di bidang tugasnya, keterbukaan, pengerahan dan alokasi sumber daya, pengawasan program kerja, kejujuran, kepedulian terhadap bawahan, sikap toleransi.

\section{Persepsi Dosen terhadap Seleksi Wakil Rektor 3}

Persepsi dosen terhadap realita seleksi berada pada kategori cukup sesuai dengan aturan yang berlaku. Tentang harapan dosen terhadap kriteria seleksi berada pada kategori sesuai dan harapan dosen terhadap realita seleksi berada pada kategori cukup sesuai. Temuan tersebut sangat sesuai dengan temuan data yang lebih bersifat kualitatif, bahwa perkembangan kemampuannya, pengalaman, keahlian yang relevan, penelitian, karya ilmiah nonpenelitian. pengabdian masyarakat pendidikan dan pengajaran, kehidupan keagamaan, kegiatan kemanusiaan, keharmonisan keluarga cukup memadai.

\section{Persepsi Dosen terhadap Seleksi Wakil Rektor 4}

Persepsi dosen terhadap realita seleksi berada pada kategori sesuai dengan aturan yang berlaku. Tentang harapan dosen terhadap kriteria seleksi berada pada kategori sesuai dan harapan dosen terhadap realita seleksi berada pada kategori cukup sesuai. Temuan tersebut sangat sesuai dengan temuan data yang lebih bersifat kualitatif, bahwa aspek akademik, kemampuan teknis fungsional, kesehatan, karya dan keharmonisan keluarga, dan kegiatan kemanusiaan cukup memadai. Beberapa aspek yang masih perlu mendapat perhatian yang serius untuk disempurnakan adalah kepemimpinan, keahlian yang relevan, manajerial pengalaman, keterbukaan, kerjasama, penghayatan peranan perguruan tinggi, kepedulian terhadap bawahan, sikap toleransi.

\section{Persepsi Dosen terhadap Seleksi Pejabat Struktural Fakultas IImu Pendidikan}

Dari analisis data sebagaimana telah dilakukan sebelumnya ditemukan bahwa persepsi dosen terhadap kriteria dan realita seleksi pejabat struktural di Fakultas Ilmu Pendidikan (FIP) berada pada rentangan kategori sesuai dan cukup sesuai dengan yang berlaku. Demikian pula tentang harapan dosen terhadap kriteria dan realita seleksi 
berada pada kategori sesuai dan harapan dosen terhadap realita seleksi berada pada rentangan kategori sesuai dan cukup sesuai.

Temuan tersebut sangat sesuai dengan temuan data yang lebih bersifat kualitatif, bahwa dalam aspek kepribadian, kepemimpinan, kehidupan keagamaan, kepedulian terhadap program peneilitian, kegiatan kemanusiaan, dan keharmonisan keluarga cukup memadai. Beberapa aspek yang masih perlu memperoleh perhatian secara serius adalah pengawasan program kerja, keterbukaan, penghayatan politik, evaluasi program kerja, keteladanan perilaku, dan kepedulian terhadap bawahan.

\section{Persepsi Dosen terhadap Seleksi Pejabat Struktural Fakultas Ilmu Sosial}

Berkaitan dengan hasil penelitian diketahui bahwa persepsi dosen terhadapkriteria dan realita seleksi pejabat struktural di Fakultas Ilmu Sosial (FIS) berada padakategori cukup sesuai dengan yang berlaku. Tentang harapan dosen terhadap kriteria dan realita seleksi berada pada kategori cukup sesuai dan harapan dosen terhadaprealita seleksi berada pada kategori cukup sesuai.

Temuan tersebut sangat sesuai dengan temuan data yang lebih bersifat kualitatif, bahwa dalam aspek kepribadian, kepemimpinan, kehidupan keagamaan, kepedulian terhadap program penelitian, kegiatan kemanusiaan, dan keharmonisan keluarga cukup memadai. Beberapa aspek yang masih perlu memperoleh perhatian secara serius adalah pengawasan program kerja, keterbukaan, penghayatan politik, evaluasi program kerja, keteladanan perilaku, kepedulian terhadap bawahan.

\section{Persepsi Dosen terhadap Seleksi Pejabat Struktural Fakultas Matematika dan Ilmu Pengetahuan Alam}

Berkaitan dengan hasil penelitian ditemukan bahwa persepsi dosen terhadap kriteria dan realita seleksi pejabat struktural di Fakultas Matematika dan Ilmu Pengetahuan Alam (FMIPA) berada pada rentangan kategori sesuai dan cukup sesuai dengan yang berlaku. Tentang harapan dosen terhadap kriteria dan realita seleksi berada pada kategori sesuai dan harapan dosen terhadap realita seleksi berada pada rentangan kategori sesuai.
Selanjutnya dari hasil analisis regresi diperoleh hasil bahwa secara bersama-sama persepsi dosen terhadap kriteria dan persepsi dosen terhadap realita seleksi memberikan sumbangan yang berarti kepada harapan dosen terhadap kriteria seleksi. Temuan tersebut sangat sesuai dengan temuan data yang bersifat kualitatif, bahwa dalam aspek kepribadian, kepemimpinan, kehidupan keagamaan, kepedulian terhadap program penelitian, kegiatan kemanusiaan, dan keharmonisan keluarga cukup memadai.

\section{Persepsi Dosen terhadap Seleksi Pejabat Struktural Fakultas Sastra}

Berkaitan dengan hasil penelitian diketahui bahwa bahwa persepsi dosen terhadap kriteria dan realita seleksi pejabat struktural di Fakultas Sastra (FS) berada pada rentangan kategori sesuai dan cukup sesuai dengan yang berlaku. Tentang harapan dosen terhadap kriteria dan realita seleksi berada pada kategori sesuai dan harapan dosen terhadap realita seleksi berada pada rentangan kategori sesuai dan cukup sesuai.

Temuan tersebut sangat sesuai dengan temuan data yang lebih bersifat kualitatif, bahwa dalam aspek kepribadian, kepemimpinan, kehidupan keagamaan, kepedulian terhadap program penelitian, kegiatan kemanusiaan, dan keharmonisan keluarga cukup memadai. Beberapa aspek yang masih perlu memperoleh perhatian secara serius adalah pengawasan program kerja, keterbukaan, penghayatan politik, evaluasi program kerja, keteladanan perilaku, kepedulian terhadap bawahan.

\section{Persepsi Dosen terhadap Seleksi Pejabat Struktural Fakultas Teknik}

Berkaitan dengan hasil penelitian diketahui bahwa persepsi dosen terhadap kriteria dan realita seleksi pejabat struktural, khususnya Dekan Fakultas Teknik (FT) berada pada kategori cukup sesuai dengan aturan yang berlaku. Sedang untuk pejabat struktural lainnya berada pada rentangan kategori sesuai dan cukup sesuai dengan aturan yang berlaku. Tentang harapan dosen terhadap kriteria dan realita seleksi khususnya untuk dekan, berada pada rentangan kategori sesuai dan cukup sesuai dan berada pada rentangan kategori sesuai dan cukup sesuai untuk pejabat struktural lainnya. 
Temuan tersebut sangat sesuai dengan temuan data yang bersifat kualitatif, bahwa dalam aspek kepribadian, kepemimpinan, kehidupan keagamaan, kepedulian terhadap program penelitian, kegiatan kemanusiaan, dan keharmonisan keluarga cukup memadai. Beberapa aspek yang masih perlu memperoleh perhatian secara serius adalah pengawasan program kerja, keterbukaan, penghayatan politik, evaluasi program kerja, keteladanan perilaku, kepedulian terhadap bawahan.

\section{Pembahasan}

Seleksi pimpinan perguruan tinggi menjadi wahana dan titik tolak melakukan perubahan menuju lembaga yang lebih baik. Setiap warga kampus akan antusias menyambut calon pimpinan yang membawa gagasan perubahan menuju perguruan tinggi yang unggul. Dosen menjadi salah satu warga kampus yang memiliki peranan strategis dalam memilih calon pimpinan perguruan tinggi. Visi dan misi yang diturunkan menjadi rencana aksi oleh calon pimpinan akan mempengaruhi dosen dalam proses seleksi pimpinan perguruan tinggi. The rector is elected by the registered students of the university and the main role of the Rector is to represent the university's students (University of Glasgow, 2014). Rektor adalah pejabat publik yang diberi tugas memimpin kampus tempat melahirkan orang-orang pintar, cerdik, dan cendikiawan (Raharjo, 2016).

Jika mengacu pada bentuk perguruan tinggi negeri (PTN), maka ada tiga bentuk PTN, yaitu PTN badan hukum, PTN satuan kerja pemerintah, dan badan layanan umum (BLU). Pada PTN badan hukum, ada majelis wali amanat yang akan menjalankan organisasi perguruan tinggi (Kemristekdikti, 2016). Memilih majelis wali amanat ialah one man one vote (Kemristekdikti, 2016). Peraturan Menteri Pendidikan Nasional Nomor 24 Tahun 2010 tentang Pengangkatan dan Pemberhentian Rektor / Ketua / Direktur pada Perguruan Tinggi yang Diselenggarakan oleh Pemerintah pasal 2 menyatakan rektor pada perguruan tinggi adalah dosen pegawai negeri sipil yang diberi tugas tambahan sebagai pemimpin perguruan tinggi. Rectors should be chosen from the internal academic organizations of universities (Soyuekerci dan Erturgut, 2009:958).
Deans and department chairs poised to sign off on strategic plans that promise to move the institution to better rankings (O'Meara, 2007:123). Moreover, the dean made a specificrecommendation in order to address the concerns expressed by suggesting that the senior administrators who directed these units meet with the academic council in order to address and remedy the dean's concerns (Metcalfe, 2006:100). Deans are the leaders in universities (Ngang, dkk., 2013:1183). Shahid menyatakan bahwa di Malaysia, the selection criteria for deans include academic qualification (Doctor of Philosophy), professional requirement, working experience of more than 10 years leadership (academic leadership and scholarship leadership), and management skills (decision making, communication, problem solving and interpersonal) (Ngang, dkk., 2013:1183).

Pemilihan pimpinan perguruan tinggi menjadi ajang membangun impian dan harapan untuk membangun universitas menuju perguruan tinggi yang berkualitas. Aspek penting dalam hal ini adalah bagaimana memberdayakan sumber belajar guna meningkatkan mutu perkuliahan. Mendirikan student book store untuk mewadahi semua sumber belajar, bekerja sama dengan berbagai pihak seperti penerbit dan bisa digunakan untuk tempat praktik sebagai ajang pembelajaran mahasiswa merupakan salah satu wujud realisasi melalui pelayanan dan penyediaan sumber belajar (Nida, 2010). Harapan yang disematkan kepada pimpinan perguruan tinggi adalah yang memiliki visi, etos kerja tangguh, dan melayani pekerjaannya, melayani kepemimpinannya dan melayani yang dipimpinnya (Siagian, 2016).

Initially, deans were much regarded as managers of academic institutions and their duties focused mainly on the administration of students which include managing, planning, budgeting, advocating, fundraising and cultural perspectives (Wolverton, dkk., 2001). However, with the twin impact of globalization and internationalization, the roles and responsibilities of deans in institutions of higher learning are far more challenging as they are regarded to act as both managers and leaders of change (Jamiana, dkk., 2013:279). The most important information deans need at their fingertips when faced with a particular challenge or opportunity (Buller, 2007). 
Academic deans, both new and seasoned, will benefit enormously from this collection of ruminations by experienced and successful academic leaders on the issues that are most prominent and often most vexing for those who enter the arena of academic leadership (Behling, 2014). Applies positive and creative leadership principles to the issue of leading change in higher education, providing a much-needed blueprint for changing the way change happens, and how the system reacts (Buller, 2014). Strategies for Success is to acquaint individuals either who are newly appointed deans or who are about to become academic deans with the typical challenges that come with such leadership positions (Krahenbuh, 2004).

\section{KESIMPULAN DAN SARAN}

\section{Kesimpulan}

Berdasarkan hasil penelitian ini, maka disimpulkan bahwa persepsi dosen terhadap kriteria, realita, dan harapan dalam pelaksanaan seleksi calon pimpinan di lingkungan UM sudah sesuai. Begitu juga pelaksanaan seleksi calon pimpinan fakultas di lingkungan UM sudah sesuai dan sangat sesuai dengan persepsi dan harapan dosen. Secara umum diketahui bahwa persepsi para dosen terhadap seleksi pejabat struktural di UM masih berada pada rentangan kategori sesuai dan cukup sesuai dengan aturan yang berlaku.

\section{Saran}

Demikian pula dengan harapan para dosen terhadap seleksi pejabat struktural di UM masih berada pada rentangan kategori sesuai dan cukup sesuai saja Dengan demikian perlu adanya upayaupaya yang harus dilakukan dalam perlaksanaan seleksi pejabat struktural untuk dapat memperbaiki persepsi dan meningkatkan harapan para dosen tersebut terhadap pelaksanaan seleksi pejabat struktural.

\section{DAFTAR RUJUKAN}

Behling, L. L. 2014. The Resource Handbook for Academic Deans. New York: Jossey-Bass.

Buller, J. L. 2007. The Essential Academic Dean: A Practical Guide to College Leadership. New York: Jossey-Bass.
Buller, J. L. 2014. Change Leadership in Higher Education: A Practical Guide to Academic Transformation. New York: Jossey-Bass.

Guilfor, P. P., dan Fruchter, B. 1978. Fundamental Statistics in Psychology and Education. Tokyo: McGrow Hill Kogaskhesha, Ltd.

Jamiana, L. S., Sidhu, G. K., dan Aperaparc, P. S. 2013. Managerial Decision Styles of Deans in Institutions of Higher Learning. $6^{\text {th }}$ International Conference on University Learning and Teaching (InCULT 2012), (Online), Procedia - Social and Behavioral Sciences, hlm. 1182-1186, (http://www. sciencedirect.com), diakses 13 Oktober 2014.

Kemristekdikti. 2016. Soal Pemilihan Rektor, ini Penjelasan Menristekdikti, (Onlien), (http://kelembagaan.ristekdikti.go.id/index. php/2016/10/28/soal-pemilihan-rektor-inipenjelasan-menristekdikti/), diakses 29 Oktober 2016.

Krahenbuh, G. S. 2004. Building the Academic Deanship: Strategies for Success. New Jersey: Rowman \& Littlefield Publishers.

Metcalfe, A. S. 2006. Knowledge Management and Higher Education: A Critical Analysis. London: Information Science Publishing.

Ngang, T. K., Prachak, B., dan Saowanee, T. 2013. Leadership Soft Skills of Deans in Three Malaysian Public Universities. $3^{\text {rd }}$ World Conference on Learning, Teaching and Educational Leadership (WCLTA-2012), (Online), Procedia - Social and Behavioral Sciences, hlm. 1182-1186, (http://www. sciencedirect.com), diakses 13 Oktober 2014.

Nida. 2010. Pilrek UM 2010-2014: dari Diskusi hingga Visi Misi, (Online), (http://komunikasi. um.ac.id/2010/05/pilrek-um-2010-2014-daridiskusi-hingga-visi-misi/), diakes 23 Maret 2011.

O’Meara, K. 2007. Striving For What? Exploring the Pursuit of Prestige. Dalam Smart, J. C. (Ed.)., Higher Education: Handbook of Theory and Research (hlm. 121-179). Dordrecht, The Netherlands: Springer.

Peraturan Menteri Pendidikan Nasional Nomor 24 Tahun 2010 tentang Pengangkatan dan Pemberhentian Rektor / Ketua / Direktur pada Perguruan Tinggi yang Diselenggarakan oleh Pemerintah, (Online), (http://www.fti. 
itb.ac.id/ wp-content/ uploads/ 2015/ 06/ Permendiknas- no.- 24- tahun- 2010-tentangPengangkatan- Pemberhentian- Rektor- dst. pdf), diakses 2 Juli 2011.

Raharjo, M. 30 Desember 2016. Rektor tak Alergi KPK Awasi Pilrek. Jawa Pos, hlm. 20.

Siagian, A. 2016. Tentang Harapan kepada Rektor Baru itu, (Online), (http://harian.analisadaily. com/opini/news/tentang-harapan-kepadarektor-baru-itu/210831/2016/02/02), diakes 2 Maret 2016.

Sonhadji, A. K. H. 1990. Dosen dalam Pengembangan Institut. Makalah Disajikan pada Short Course bagi Tenaga Fungsional Akademik Perguruan Tinggi, Semarang, 11 s.d. 30 Juni.

Soyuekerci, S., dan Erturgut, R. 2009. Professional Backgrounds of Rectors at Turkish Universities: A Critical Evaluation. World
Conference on Educational Sciences 2009, (Online), Procedia - Social and Behavioral Sciences, hlm. 958-962, (http://www. sciencedirect.com), diakses 13 Oktober 2014. University of Glasgow. 2014. Rector Elections, (Online), (https://www.glasgowstudent.net/ about/rector-elections/), diakses 2 Januari 2014.

Wolverton, M., Gmelch, W., Montez, J., dan Nies, C. 2001. The Changing Nature of the Academic Deanship: ASHE-ERIC Higher Education Research Report. New York: Jossey-Bass.

Yukl, G. A. 1991. Leadership in Organizations. Englewood Cliffs: Prentice Hall, Inc. 